\title{
Increase in Insulin Response after Treatment of Overt Maturity-Onset Diabetes is Independent of the Mode of Treatment
}

\author{
K. Kosaka, T. Kuzuya, Y. Akanuma, and R. Hagura \\ Third Department of Internal Medicine, University of Tokyo, Tokyo, Department of Medicine, Jichi Medical School, Tochigi-ken, \\ and Institute for Adult Diseases, Asahi Life Foundation, Tokyo, Japan
}

Summary. The changes in insulin response to a $100 \mathrm{~g}$ glucose tolerance test after treatment by diet, sulphonylurea and insulin were compared in non-ketotic diabetic patients who had fasting blood glucose concentrations higher than $160 \mathrm{mg} / 100 \mathrm{ml}$. Patients were selected so that their pre-treatment and posttreatment blood glucose levels were comparable between different treatment groups. Their insulin responses were poor initially but increased significantly when the diabetic state was improved by each treatment. The degree of improvement of insulin response was similar between different treatment groups, when their fasting blood glucose decreased below $140 \mathrm{mg} / 100 \mathrm{ml}$ and the glucose tolerance curves were improved to a similar extent. Pre- and post-treatment $\Sigma$ IRI values (sum of insulin values during glucose tolerance test, mean \pm SD) were 102 \pm 50 and $200 \pm 37 \mu \mathrm{U} / \mathrm{ml}$ in diet-treated group $(\mathrm{n}=$ 28), $90 \pm 40$ and $195 \pm 53 \mu \mathrm{U} / \mathrm{ml}$ in sulphonylureatreated group $(\mathrm{n}=48)$, and $83 \pm 28$ and $193 \pm$ $38 \mu \mathrm{U} / \mathrm{ml}$ in insulin-treated group $(\mathrm{n}=13)$, respectively. The data suggest that the poor insulin response in overt diabetes results not only from an inherent insensitivity of B-cells to glucose but also from the metabolic derangement of diabetes. Poor insulin response and overtly diabetic metabolism seems to form a vicious cycle.

Key words: Improvement of insulin response, glucose tolerance test, treatment of diabetes, diet treatment, sulphonylurea treatment, insulin treatment.

It is established that the insulin secretory response to a glucose tolerance test is diminished in moderate to severe diabetes [1]. In such patients, insulin responses remain subnormal even if their diabetic state is much improved $[2,3]$. In general, the insulin response is lower in proportion to the height of the fasting blood glucose (FBG). It is also known that insulin secretion can vary with the changes of diabetic state during the course of treatment by diet, sulphonylureas and insulin [4-6]. Although insulin responses never or seldom become completely normal in definite diabetes [3], there is often a partial recovery of insulin responses to oral glucose after treatment in patients who had very poor insulin responses initially. We were interested in the mechanism of this partial recovery of insulin response and tried to find out whether the degree of recovery is related to the mode of treatment of diabetes by diet, sulphonylureas and insulin.

\section{Materials and Methods}

The subjects were mainly patients seen regularly at the diabetic out-patient clinic of the University of Tokyo Hospital. They were stable and non-ketotic, and were overtly diabetic before treatment. Some features of these patients are shown in Table 1. Before and after treatment by diet alone $(\mathrm{n}=28)$, sulphonylurea plus diet $(n=48)$ or insulin plus diet $(n=13)$, they were tested with a $100 \mathrm{~g}$ oral glucose tolerance test (GTT). Diet treatment consisted of 25 to $30 \mathrm{Cal}$ and $1-1.5 \mathrm{~g}$ protein per $\mathrm{kg}$ ideal body weight; about $50 \%$ of total energy was given as carbohydrate. The type of treatment was determined by the physicians. GTT was carried out after an overnight fast of 12 to 14 hours. Medications including oral hypoglycaemic agents and insulin were withheld on the day of examination until the end of GTT. Patients were receiving no other medications. Patients on insulin were treated by a single dose of lente (mixture of pork and beef) or NPH (beef) insulin before breakfast. In order to avoid the interference with the radioimmunoassay by insulin antibodies, the post-treatment GTT was carried out within two weeks after starting insulin treatment. In patients who were treated by diet or sulphonylureas, the posttreatment GTT was performed within 6 months. Patients with other metabolic or endocrine diseases besides diabetes mellitus were excluded. Control subjects were non-obese, without family 
(A) Initial $\Sigma B G: 1600 \sim 2200 \mathrm{mg} / 100 \mathrm{~m} \ell$

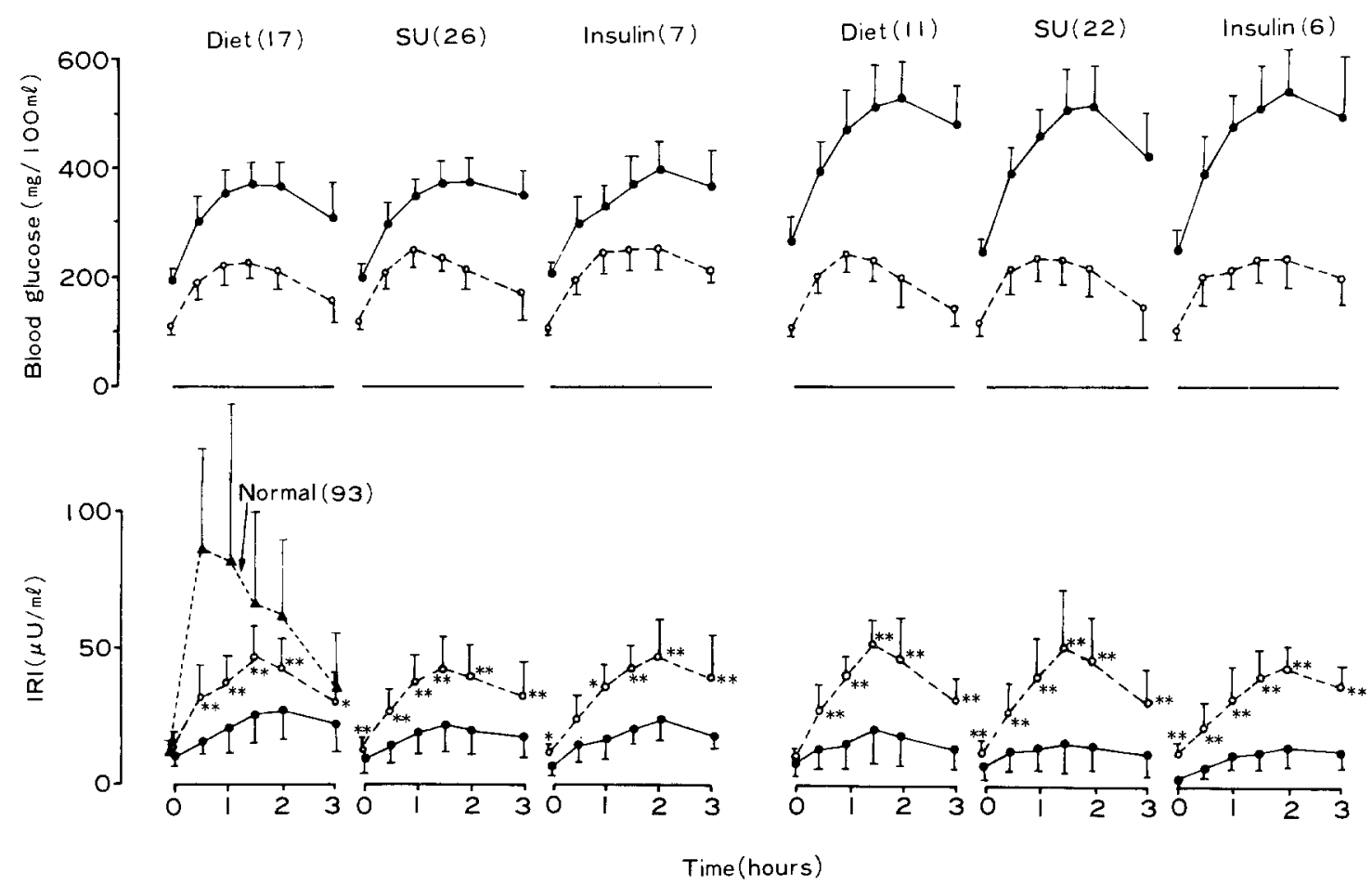

Fig. 1. Changes in blood glucose and plasma insulin during $100 \mathrm{~g}$ glucose tolerance test before and after treatment of overtly diabetic patients (Mean $\pm \mathrm{SD}$ ). Initial $\Sigma \mathrm{BG}$ is the sum of six blood glucose values during $100 \mathrm{~g}$ glucose tolerance test before treatment. * and ** post-treatment insulin values are significantly different from the corresponding pre-treatment values by $p<0.05$ and $p<0.01$, respectively. Numbers in parentheses indicate number of patients; - before treatment, $\mathrm{O}-\mathrm{O}$ after treatment

Table 1. Some features of diabetic patients and control subjects

\begin{tabular}{|c|c|c|c|c|c|}
\hline & Number & Male:Female & Age & Duration of diabetes & Weight index (\%) \\
\hline $\begin{array}{l}\text { Diabetics } \\
\text { Diet }\end{array}$ & 28 & $16: 12$ & $\begin{array}{l}36-65 y^{a} \\
(46)\end{array}$ & $\begin{array}{l}2 m-7 y^{a} \\
(2 y 8 m)\end{array}$ & $\begin{array}{l}+8 \text { to }+46 \\
(+22)\end{array}$ \\
\hline Sulphonylurea & 48 & $30: 18$ & $\begin{array}{l}35-70 y \\
(51)\end{array}$ & $\begin{array}{l}3 \mathrm{~m}-8 \mathrm{y} \\
(3 \mathrm{y} 2 \mathrm{~m})\end{array}$ & $\begin{array}{l}-14 \text { to }+23 \\
(+6)\end{array}$ \\
\hline Insulin & 13 & $8: 5$ & $\begin{array}{l}21-62 y \\
(40)\end{array}$ & $\begin{array}{l}1 \mathrm{~m}-9 \mathrm{y} \\
(3 \mathrm{y} 5 \mathrm{~m})\end{array}$ & $\begin{array}{l}-21 \text { to }+15 \\
(-3)\end{array}$ \\
\hline Controls & 93 & $64: 29$ & $\begin{array}{l}21-81 y \\
(37)\end{array}$ & -- & $\begin{array}{l}-17 \text { to }+9 \\
(-4)\end{array}$ \\
\hline
\end{tabular}

Numbers in the parentheses are mean values

${ }^{\mathrm{a}} \mathrm{m}=$ months, $\mathrm{y}=$ years

history of diabetes and with glucose tolerance curves in which $60-$ minute and 120 minute blood glucose values were less than 160 and $120 \mathrm{mg} / 100 \mathrm{ml}$ respectively. Weight index was calculated as the percentage of the ideal body weight (i. e. (body height $(\mathrm{cm})-$ 100) $\times 0.9)$.

GTT was performed using $300 \mathrm{ml}$ Trelan G 50 (Simizu Seiyaku Co., Japan). Plasma glucose and insulin responses after drinking this solution were nearly the same as after a $100 \mathrm{~g}$ glucose load [7]. Blood glucose was determined with whole blood taken from a cut on the earlobe before and 30,60,90,120 and 180 min after drinking the solution. Samples for serum or plasma insulin assay were taken at the same time from an antecubital vein. Blood glucose was measured by Technicon Autoanalyser [8] or by a glucose oxidase method (Glucostat, Worthington). The latter method gave about $5 \mathrm{mg} / 100 \mathrm{ml}$ lower glucose values than the former method. Insulin was measured by a double-antibody radioimmunoassay [9]: the minimal detectable value by the routine assay was $2-3 \mu \mathrm{U} /$ $\mathrm{ml}$ and the coefficient of variation was $3-5 \%$. 
Table 2. Changes in weight, fasting blood glucose and fasting insulin levels before and after each treatment

\begin{tabular}{|c|c|c|c|c|c|c|c|c|c|}
\hline \multirow[t]{2}{*}{$\begin{array}{l}\text { Mode of } \\
\text { treatment }\end{array}$} & \multirow[t]{2}{*}{$\begin{array}{l}\text { Initial } \Sigma B G \\
(\mathrm{mg} / 100 \mathrm{ml})\end{array}$} & \multirow[t]{2}{*}{ Number } & \multirow{2}{*}{$\begin{array}{l}\text { Intervals } \\
\text { between } \\
\text { two GTTs }\end{array}$} & \multicolumn{2}{|c|}{$\begin{array}{l}\text { Weight index } \\
(\%)\end{array}$} & \multicolumn{2}{|c|}{$\begin{array}{l}\text { FBG } \\
(\mathrm{mg} / 100 \mathrm{ml})\end{array}$} & \multicolumn{2}{|c|}{$\begin{array}{l}\text { Fasting insulin } \\
(\mu \mathrm{U} / \mathrm{ml})\end{array}$} \\
\hline & & & & Before & After & Before & After & Before & After \\
\hline \multirow[t]{2}{*}{ Diet } & $1600-2200$ & 17 & $\begin{array}{l}4.2 \pm 2.0 \mathrm{~m}^{\mathrm{c}} \\
(1-6 \mathrm{~m})\end{array}$ & $+20 \pm 9$ & $+10 \pm 8^{\mathrm{d}}$ & $190 \pm 23$ & $109 \pm 15^{e}$ & $10 \pm 4$ & $13 \pm 7$ \\
\hline & $>2200$ & 11 & $\begin{array}{c}3.5 \pm 2.1 \mathrm{~m} \\
(1-6 \mathrm{~m})\end{array}$ & $+26 \pm 13$ & $+14 \pm 12^{d}$ & $262 \pm 50$ & $109 \pm 12^{e}$ & $8 \pm 5$ & $10 \pm 5$ \\
\hline \multirow[t]{2}{*}{ Sulphonylurea $^{a}$} & $1600-2200$ & 26 & $\begin{array}{l}1.9 \pm 1.1 \mathrm{~m} \\
(1-4 \mathrm{~m})\end{array}$ & $+4 \pm 12$ & $+4 \pm 11$ & $194 \pm 28$ & $114 \pm 12^{e}$ & $9 \pm 5$ & $13 \pm 5^{e}$ \\
\hline & $>2200$ & 22 & $\begin{array}{l}3.3 \pm 1.7 \mathrm{~m} \\
(1-6 \mathrm{~m})\end{array}$ & $+6 \pm 14$ & $+5 \pm 12$ & $246 \pm 31$ & $113 \pm 16^{\circ}$ & $7 \pm 5$ & $12 \pm 6^{\mathrm{e}}$ \\
\hline \multirow[t]{2}{*}{ Insulin ${ }^{\mathrm{b}}$} & $1600-2200$ & 7 & $\begin{array}{l}11 \pm 1 d \\
(10-14 d)\end{array}$ & $-2 \pm 14$ & $-1 \pm 5$ & $201 \pm 22$ & $108 \pm 12^{e}$ & $6 \pm 4$ & $12 \pm 2^{\mathrm{d}}$ \\
\hline & $>2200$ & 6 & $\begin{array}{c}12 \pm 1 d \\
(11-14 d)\end{array}$ & $-8 \pm 5$ & $-6 \pm 6$ & $245 \pm 39$ & $100 \pm 15^{e}$ & $4 \pm 5$ & $12 \pm 4^{\mathrm{e}}$ \\
\hline
\end{tabular}

${ }^{a}$ Five patients were treated daily by tolbutamide $(1.0-1.5 \mathrm{~g}), 17$ patients by chlorpropamide $(0.25-0.5 \mathrm{~g})$ and 26 patients by glibenclamide $(2.5-7.5 \mathrm{mg})$

${ }^{b}$ Seven patients were treated by lente insulin and 6 patients by NPH insulin (14-30 U/day)

c $\mathrm{m}=$ months, $\mathrm{d}=$ days. Numbers in parentheses are ranges

${ }^{d}$ and ${ }^{e}$ significantly different from corresponding pretreatment values by a paired $t$-test $(p<0.05$ and $p<0.01$, respectively)

In order to compare different treatment groups with similar severity of diabetes and with similar degree of improvement, only the patients whose pre-treatment FBG and $\Sigma B$ B (i. e. the sum of six blood glucose values during the GTT) exceeded $160 \mathrm{mg} / 100 \mathrm{ml}$ and $1600 \mathrm{mg} / 100 \mathrm{ml}$, and whose post-treatment FBG and $\Sigma$ BG fell below $140 \mathrm{mg} / 100 \mathrm{ml}$ and $1400 \mathrm{mg} / 100 \mathrm{ml}$ respectively, were selected for the analysis.

\section{Results}

\section{Comparison of Initial Characteristics} of Different Treatment Groups

The initial FBG and blood glucose changes during GTT were not significantly different between different groups because of the selection of the patients by FBG and $\Sigma$ BG criteria. Their pre-treatment insulin responses were similar in all treatment groups, and were markedly decreased as compared to normal subjects. When each treatment group was subdivided into two subgroups with $\Sigma$ BG values below and above $2200 \mathrm{mg} / 100 \mathrm{ml}$, the subgroup with $\Sigma$ BG less than $2200 \mathrm{mg} / 100 \mathrm{ml}$ had significantly greater insulin responses as expressed by $\Sigma$ IRI (i. e. the sum of six insulin values during the GTT). The blood glucose and insulin changes during GTT did not differ significantly from each other between subgroups with similar $\Sigma$ BG values (Fig. 1).

Although the initial blood glucose and insulin responses were comparable, the mean age and the degree of obesity were different among treatment groups (Table 1). Patients treated by diet alone were more obese than the other two groups. The insulin-
Table 3. Changes in $\Delta \mathrm{IRI} / \Delta \mathrm{BG}$ before and after each treatment (mean $\pm \mathrm{SD}$ ). $\Delta \mathrm{IRV} / \Delta \mathrm{BG}$ means the ratio of increment of insulin level $(\mu \mathrm{U} / \mathrm{ml})$ to that of blood glucose $(\mathrm{mg} / 100 \mathrm{ml}) 30$ minutes after a $100 \mathrm{~g}$ glucose load. Each treatment group is subdivided by the initial $\Sigma$ BG (sum of blood glucose values during $100 \mathrm{~g} \mathrm{GTT}$ )

\begin{tabular}{llrll}
\hline $\begin{array}{l}\text { Mode of } \\
\text { treatment }\end{array}$ & $\begin{array}{l}\text { Initial } \Sigma \mathrm{BG} \\
(\mathrm{mg} / 100 \mathrm{ml})\end{array}$ & Number $\Delta \mathrm{IRI} / \Delta \mathrm{BG}$ \\
\hline Diet & $1600-2200$ & 17 & $0.06 \pm 0.04$ & $0.28 \pm 0.23^{\mathrm{a}}$ \\
& $>2200$ & 11 & $0.04 \pm 0.05$ & $0.20 \pm 0.11^{\mathrm{a}}$ \\
Sulphonylurea & $1600-2200$ & 26 & $0.05 \pm 0.05$ & $0.16 \pm 0.10^{\mathrm{a}}$ \\
& $>2200$ & 22 & $0.03 \pm 0.03$ & $0.17 \pm 0.12^{\mathrm{a}}$ \\
Insulin & $1600-2200$ & 7 & $0.12 \pm 0.12$ & $0.19 \pm 0.26$ \\
& $>2200$ & 6 & $0.02 \pm 0.03$ & $0.18 \pm 0.17$ \\
\hline
\end{tabular}

a Significantly different from corresponding pre-treatment values by a paired t-test $(\mathrm{p}<0.01)$

treated group were the youngest and the sulphonylurea-treated group the oldest. Diet-treated patients in each subgroup lost weight (Table 2); the mean weight index was reduced from $+22 \%$ to $+11 \%$ after treatment. There were no significant weight changes during the treatment in sulphonylurea and insulin groups.

\section{Changes in Insulin Responses during GTT after Different Modes of Treatment}

After treatment by diet, sulphonylurea or insulin, the mean FBG level of each group was decreased below $120 \mathrm{mg} / 100 \mathrm{ml}$ and the glucose tolerance curve markedly improved (Fig. 1). The degree of improvement of blood glucose did not differ significantly between 


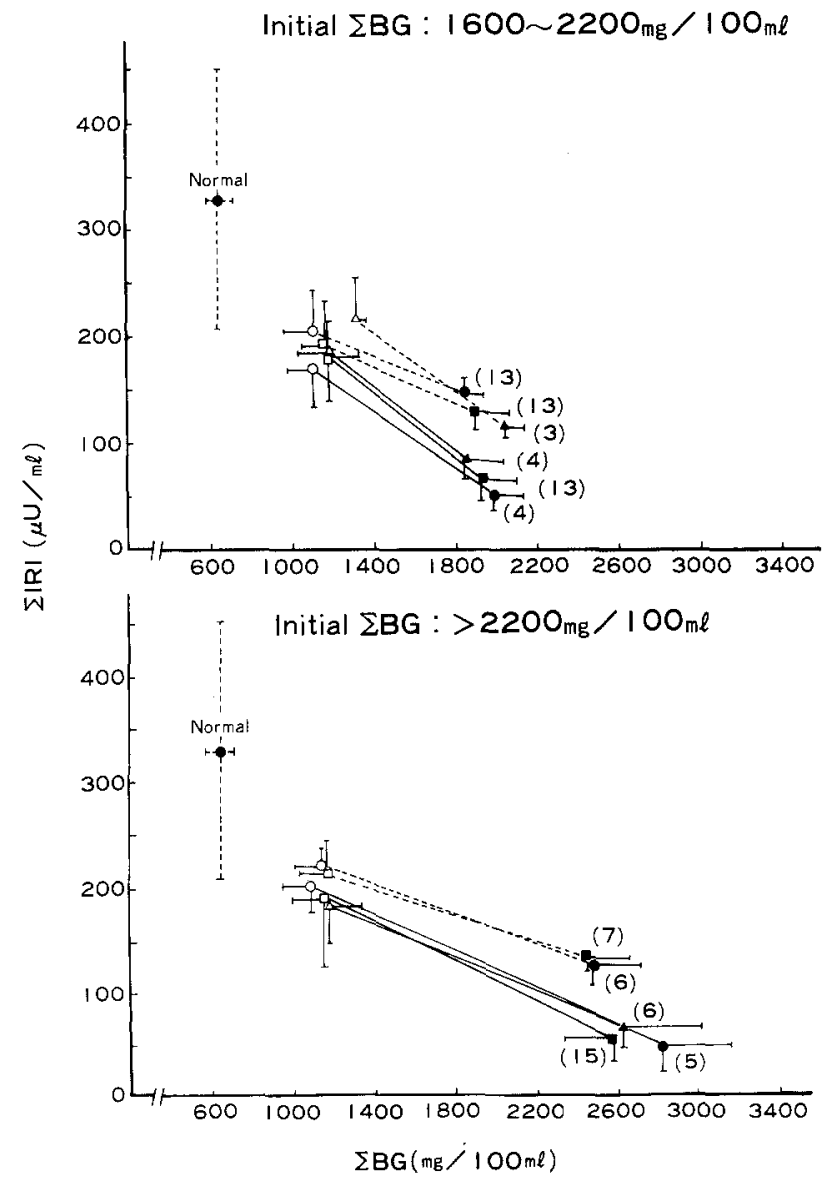

Fig. 2. Changes in sum of blood glucose values ( $\Sigma$ BG) and plasma insulin values $(\Sigma \mathrm{IRI})$ during $100 \mathrm{~g}$ glucose tolerance test before and after treatment of diabetic patients (Mean $\pm \mathrm{SD}$ ). Solid symbols represent the data before treatment by diet alone $(\mathbf{O})$, sulphonylurea plus diet $(\boldsymbol{\square})$ or insulin plus diet $(\boldsymbol{\Delta})$. Open symbols $(O, \square$ and $\triangle$ ) are the corresponding data after each treatment, respectively. Solid and broken lines represent subgroups in which pre-treatment $\Sigma$ IRI values were below $100 \mu \mathrm{U} / \mathrm{ml}$ and above $100 \mu \mathrm{U} / \mathrm{ml}$, respectively. Numbers in parentheses indicate number of patients. Post-treatment $\Sigma$ IRI values are all significantly greater than the corresponding pre--treatment values $(p<0.01$ or $\mathrm{p}<0.05)$

different treatment groups. There were no differences between the post-treatment glucose tolerance curves whether initial $\Sigma$ BG values of patients were below or above $2200 \mathrm{mg} / 100 \mathrm{ml}$ because only patients with post-treatment $\Sigma$ BG below $1400 \mathrm{mg} /$ $100 \mathrm{ml}$ entered the study.

The mean insulin response of each treatment group was significantly increased after the improvement of glucose tolerance. The post-treatment insulin curves were still subnormal, and they were similar in all the subgroups irrespective of the modes of treatment. Despite the differences in pre-treatment insulin responses between subgroups with different initial $\Sigma$ BG values, the insulin responses were increased to nearly the same extent after the improvement of their glucose tolerance. Fasting insulin levels increased significantly in sulphonylurea and insulin-treated groups (Table 2). The ratios of increment of plasma insulin to that of blood glucose 30 minutes after the glucose load ( $\Delta \mathrm{IRI} / \Delta \mathrm{BG}$ ) increased significantly in diet and sulphonylureatreated groups but never reached the normal range (lower limit: 0.5) [2] (Table 3).

The changes of $\Sigma$ IRI values are plotted against those of $\Sigma$ BG values in Figure 2. In this figure, each subgroup is further subdivided into two small subgroups according to their initial $\Sigma$ IRI values. In all subgroups, $\Sigma$ IRI increased when $\Sigma$ BG values decreased $(\mathrm{p}<0.01)$. The mean post-treatment $\Sigma$ IRI values in subgroups with higher initial $\Sigma$ IRI tended to be higher than those in corresponding subgroups with lower initial $\Sigma$ IRI, but the differences were not significant. The post-treatment $\Sigma$ IRI values did not differ significantly also between different treatment groups.

\section{Discussion}

The present study deals with insulin responses in overtly diabetic patients who had initial fasting hyperglycaemia exceeding $160 \mathrm{mg} / 100 \mathrm{ml}$. These patients almost invariably have poor insulin responses to a glucose load $[2,10,11]$. We have shown a significant increase in insulin responses when the diabetic state was improved whether by diet, sulphonylureas or insulin. The three treatment groups may not readily be comparable, because their initial features were not homogenous with regard to age and the degree of obesity, and the selection of each treatment was not randomised. The intervals between two GTTs differed among different groups. Despite these problems, the present data suggest that the degree of improvement of insulin responses was similar in all patients whose post-treatment $\Sigma$ BG values were improved to a similar extent (i. e. below $1400 \mathrm{mg} / 100 \mathrm{ml}$ ). Improvement did not depend on the initial $\Sigma$ BG or the initial $\Sigma$ IRI values.

This partial recovery of insulin response indicates that the initial poor insulin response is not solely due to irreversible damage to $\mathrm{B}$ cells. The increase in insulin release in the face of lesser hyperglycaemia suggests that $\mathrm{B}$ cell responsiveness to glucose was greatly improved during the amelioration of their diabetic state. The relationship between improvement of glucose tolerance and increase in insulin response, could be interpreted in two ways. Acute phase insulin release after a glucose load is considered to play an important role for the subsequent 
glucose disposal $[12,13]$, so it is reasonable to assume that the improvement of glucose tolerance was brought about by the increase in insulin response following each treatment. Another interpretation is that the lowering of excessive hyperglycaemia may be a cause rather than the result of the increase in insulin response. Similar suggestions have already been proposed by Perkins et al. [5], Turner and Holman [6], and Fukumoto et al. [14], who have reported the enhancement of endogenous insulin secretion following various anti-diabetic treatments.

The three different treatments of diabetes presumably act in different ways to improve the diabetic state. Dietary restriction may restore tissue sensitivity to insulin, thereby reducing the requirement for insulin; sulphonylureas may act primarily by stimulating insulin release [15] or by some other extra-pancreatic mechanisms [16, 17] such as an increase in insulin receptors [18]; the injection of insulin would directly supplement the endogenous secretion as well as "resting" the B cells. In obese individuals with normal glucose tolerance, a decrease in body weight is associated with a decrease in insulin release [19]. It is controversial whether exogenous insulin affects endogenous insulin secretion directly, but a fall in blood glucose after exogenous insulin is usually followed by a decrease in insulin or C-peptide secretion in normal man and animals $[20,21]$. For these reasons, it is unlikely that diet restriction and insulin treatment per se exerted direct insulinotrophic actions in overtly diabetic patients. We presume, therefore, that the treatment of overt diabetes improved the metabolic derangement, which perhaps exerted favourable effects on $\mathrm{B}$ cell function. The resulting improved insulin release probably contributed, in its turn, to improve further the metabolic aberrations. In the insulin-treated group, however, the possibility cannot be ruled out that exogenous insulin injected one day before the second GTT had not been cleared completely and contributed to the post-treatment fasting insulin levels.

It appears that B cells cannot function optimally when the fasting blood glucose exceeds $160 \mathrm{mg} /$ $100 \mathrm{ml}$. In a few patients with steroid-induced diabetes, we observed that the insulin response to glucose was enhanced when glucose tolerance was slightly impaired, but markedly diminished later when fasting glucose levels exceeded $160 \mathrm{mg} / 100 \mathrm{ml}$ (unpublished data). It seems that B cells respond to a slight to moderate hyperglycaemia by increased output of insulin, but fail to keep up with more severe and sustained hyperglycaemia by a further increase in insulin release. Whether this functional impairment of insulin release is caused by overstimulation [6], or by a gap between synthesis and release of insulin [5], or through inhibition by an $\alpha$-receptor mechanism [22], is unclear. The mechanism of the chronic clinical effect of sulphonylurea drugs is controversial [16, 17]. The present results suggest that the increase in insulin release in diabetic patients during treatment by sulphonylureas cannot simply be taken as an evidence of their direct insulinotrophic effect on B cells.

As reported previously, insulin responses in definite diabetes almost always remain subnormal even after good recovery [2, 3], suggesting an inherent decrease in $B$ cell responsiveness to glucose. The present data suggest that there is also a functional impairment of insulin release mechanism in patients with overt fasting hyperglycaemia. It may form a vicious cycle to aggravate hyperglycaemia further and to cause an even lower insulin response. Insulin release appears to be partially restored after the reduction of hyperglycaemia by each means of treatment. This interpretation seems to apply, to some extent, also for juvenile-onset diabetics, whose insulin secretory capacity is known to recover temporarily after vigorous treatment $[23,24]$.

\section{References}

1. Seltzer, H. S.; Allen, E.W., Herron, A. L., Jr., Brennan, M. T.: Insulin secretion in response to glycemic stimulus; Relation of delayed initial release to carbohydrate intolerance in mild diabetes mellitus. J. Clin. Invest. 46, 323-335 (1967)

2. Kosaka, K., Hagura, R., Kuzuya, T.: Insulin responses in equivocal and definite diabetes, with special reference to subjects who had mild glucose intolerance but later developed definite diabetes. Diabetes 26, 944-952 (1977)

3. Kosaka, K., Hagura, R., Kuzuya, T., Kuzuya, N.: Insulin secretory response of diabetics during the period of improvement of glucose tolerance to normal range. Diabetologia 10, 775-782 (1974)

4. Chu, P.-C., Conway, M. J., Krouse, H. A., Goodner, C. J.: The pattern of response of plasma insulin and glucose to meals and fasting during chlorpropamide therapy. Ann. Intern. Med. 68, 757-769 (1968)

5. Perkins, J. R., West, T. E. T., Sönksen, P. H., Lowy, C., Iles, C.: The effects of energy and carbohydrate restriction in patients with chronic diabetes mellitus. Diabetologia 13, 607-614 (1974)

6. Turner, R. C., Holman, R. R.: Beta cell function during insulin or chlorpropamide treatment of maturity-onset diabetes mellitus. Diabetes 27 (Suppl. 1), 241-246 (1978)

7. Nakao, M., Ito, M., Sakon, J., Kondo, S.: Changes of blood sugar, insulin and non-esterified fatty acid after Trelan G 50 and glucose loading. A comparative study. J. Jpn. Diab. Soc. 15, 314-315 (1972) (in Japanese)

8. Hoffman, W. S.: A rapid photoelectric method for determination of glucose in blood and urine. J. Biol. Chem. 120, 52-55 (1937)

9. Kanazawa, Y., Kuzuya, T., Ide, T., Kosaka, K.: Plasma insulin responses to glucose in femoral, hepatic and pancreatic veins in dogs. Am. J. Physiol. 211, 442-448 (1966)

10. Savage, P. J., Dippe, S. E., Bennett, P. H., Gorden, P., Roth, J., Rushforth, N. B., Miller, M.: Hyperinsulinemia and hypoin- 
sulinemia. Insulin responses to oral carbohydrate over a wide spectrum of glucose tolerance. Diabetes 24, 362-368 (1975)

11. Reaven, G. M., Miller, R. G.: An attempt to define the nature of chemical diabetes using a multidimensional analysis. Diabetologia 16, 17-24 (1979)

12. Cahill, G. F., Jr.: Physiology of insulin in man. Diabetes 20 , 785-799 (1971)

13. Brunzell, J. D., Robertson, R. P., Lerner, R. L., Hazzard, W. R., Ensinck, J. W., Bierman, E. L., Porte, D., Jr.: Relationships between fasting plasma glucose levels and insulin secretion during intravenous glucose tolerance tests. J. Clin. Endocrinol. Metab. 42, 222-229 (1976)

14. Fukumoto, Y., Ichihara, K., Tarui, S.: Enhanced endogenous insulin secretion after treatment with monocomponent insulin. Endocrinol. Jpn. 24, 457-461 (1977)

15. Loubatierès, A.: Physiological and pharmacological aspects of the central role of the pancreas in the mode of action of hyperglycemic sulfonamides. Acta Diabetol. Lat. 6 (Suppl. 1), 216-255 (1969)

16. Feldman, J.M., Lebovitz, H. E.: Appraisal of the extrapancreatic action of sulfonylureas. Arch. Intern. Med. 123, 314-322 (1969)

17. Shenfield, G. M., Logan, A., Shirling, D., Baird, J.: Plasma insulin and glucose levels in maturity onset diabetics treated with chlorpropamide. Diabetologia 13, 367-371 (1977)

18. Feinglos, M. N., Lebovitz, H. E.: Sulphonylureas increase the number of insulin receptors. Nature 276, 183-184 (1978)

19. Kosaka, K., Hagura, R., Odagiri, R., Saito, F., Kuzuya, T.: Effect of weight changes on serum insulin response in subjects with normal oral glucose tolerance. J. Clin. Endocrinol. Metab. 35, 655-658 (1972)

20. Horwitz, D. L., Rubenstein, A.H., Reynolds, C., Molnar, G. D., Yanaihara, N.: Prolonged suppression of insulin release by insulin-induced hypoglycemia: Demonstration by C-peptide assay. Horm. Metab. Res. 7, 449-452 (1975)

21. Sando, H., Kanazawa, Y., Kuzuya, T.: Effect of bonito insulin on endogenous insulin secretion in dogs. Am. J. Physiol. 218, 1357-1362 (1970)

22. Robertson, P., Halter, J. B., Porte, D., Jr.: A role for alphaadrenergic receptors in abnormal insulin secretion in diabetes mellitus. J. Clin. Invest. 57, 791-795 (1976)

23. Block, M. B., Mako, M. E., Steiner, D. F., Rubenstein, A. H.: Diabetic ketoacidosis. Evidence of C-peptide and proinsulin secretion following recovery. J. Clin. Endocrinol. Metab. 35, 402-406 (1972)

24. Block, M. B., Rosenfield, R. L., Mako, M. E., Steiner, D. F., Rubenstein, A. H.: Sequential changes in beta cell function in insulin-treated diabetic patients assessed by C-peptide immunoreactivity. N. Engl. J. Med. 288, 1144-1148 (1973)

Received: February 20, 1979,

and in revised form: July 17, 1979

Dr. Takeshi Kuzuya

Department of Medicine

Jichi Medical School

Tochigi-ken, 329-04

Japan 